Article

\title{
Innovativeness of Tourism Enterprises: Example of Poland
}

\author{
Eugenia Panfiluk (1)
}

check for updates

Citation: Panfiluk, E. Innovativeness of Tourism Enterprises: Example of Poland. Sustainability 2021, 13, 1024. https://doi.org/10.3390/su13031024

Academic Editor: Kyle

Maurice Woosnam

Received: 26 December 2020

Accepted: 11 January 2021

Published: 20 January 2021

Publisher's Note: MDPI stays neutral with regard to jurisdictional claims in published maps and institutional affiliations.

Copyright: (C) 2021 by the author. Licensee MDPI, Basel, Switzerland. This article is an open access article distributed under the terms and conditions of the Creative Commons Attribution (CC BY) license (https:/ / creativecommons.org/licenses/by/ $4.0 /)$.
Faculty of Engineering Management, Bialystok University of Technology, 15-351 Bialystok, Poland; e.panfiluk@pb.edu.pl; Tel.: +48-793-707-833

\begin{abstract}
The main aim of this article was to define the innovativeness of the tourism sector in crossindustry terms. The specific objectives were to identify categories of innovations implemented by tourism enterprises with division by industry branches, and to identify the differences and similarities of the innovations implemented by tourism enterprises in terms of the industry in which they operate. A conceptual framework, based on existing literature, was developed to analyze the innovation process. The research was carried out using the method of a diagnostic survey with interview elements, according to a structured research questionnaire using the telephone interview technique. The results show that tourism enterprises are characterized by average and low innovativeness. From the point of view of assessing the impact of innovation on market behavior in the tourism sector, there are no so-called disruptive innovations, which could have a decisive impact on market changes and replace the existing and constantly improved products, services, and processes. There are sustaining innovations that improve the functioning of companies, which do not affect the market changes, but do compete with the existing solutions on existing terms. However, incremental and adaptive innovations constitute an important part of innovation; this process proves the development of tourism companies and has an impact on the improvement of the situation of the entire economy.
\end{abstract}

Keywords: innovations; classification of innovations; tourist services; creative (radical) innovations; imitative innovations; adaptive innovations; secondary (apparent) innovations

\section{Introduction}

Many researchers have indicated that the issue of innovation in the literature is quite poorly developed [1-4]. It has been indicated that many areas are not covered, including the nature of innovation in tourism, whereas the degree of involvement of enterprises in incremental innovation has not been studied [5,6], most research is descriptive and/or analytical, and there is need for more empirical research and quantitative evidence [7-9]. It is also believed that there is no cross-industry research to examine innovation in tourism firms across different segments of the tourism industry $[1,5,10]$. A review of the research conducted in Central Europe, particularly in Poland, confirms the above conclusions. The conducted research on the comparison of the innovativeness of the service sector with the production sector indicates that the service sector in Poland still has a lower innovation index than the manufacturing index [11]. Studies by Alsos et al., Hoarau and Kline, and Krizaj et al. showed that the tourism sector is not very innovative [12-14].

A review of the main research findings in the literature on tourism industry innovation shows that businesses have no choice but to innovate. The most important factor stimulating the implementation of innovations is market competition [4,12,13,15-18]. Businesses have to cope with rapidly changing external markets. It has been proven that companies facing competitors are 1.6 times more likely to implement innovations (in this case, marketing ones) than those that do not have competition $[19,20]$. The probability of implementing innovations increases with the increase in the number of competitive companies within the framework of which the enterprise operates [21]. There are indications that the implementation of innovations, in particular by micro, small and medium (SMEs), is necessary for survival in the industry $[2,5,18,22,23]$. Moreover, it has been proven that regions in 
which enterprises create and implement innovations are able to develop more dynamically than those who lack them and have a limited ability to adapt [24]. There are also studies showing that innovation, in particular in peripheral areas, accelerate the economic catchingup [2,25,26], Innovations also contribute to the opening of new destinations [27]. Summing up, it should be pointed out that the most important research gap is the insufficient number of empirical studies in the field of innovation in the tourism sector, in particular in the cross-industry approach. On the basis of the identified research gap, the research goal was formulated. The aim of this article was to define the innovativeness of the tourism sector in cross-industry terms, and to identify categories of innovations implemented by tourism enterprises, broken down by industry. This allowed identifying the differences and similarities of the innovations implemented by tourism enterprises in terms of the industry in which they operate. The article is divided into sections. The first section contains the review of research in the field of innovation in the tourism sector, including in the region under study. The second section describes the methodology of data collection and the methodology of data analysis. The obtained results are described in detail in the next section. The last section is divided into parts, containing a discussion, conclusions, contributions to science, directions for future research, and management recommendations.

\section{Innovations in the Tourism Sector}

The concept of innovation in the literature was introduced by the Austrian economist Joseph Schumpeter. He treated innovation as any action that resulted in [28] introduction of new products to the market or improving those that already exist, introduction of a new or improved production method, implementation of new methods of buying or selling, opening of a new market for the supply, sale, and distribution of production, acquisition of a new source of semi-finished products or raw materials, or implementation of changes in the method of production.

The classic Shumpeterian approach to innovation related to manufacturing enterprises has evolved along with the development of the economy, and it now applies to all forms of economic activity, including services, as reflected in the definition of innovation: [29,30] innovation is a specific tool of an entrepreneur, by means of which he uses the ongoing change as an opportunity for another business or service [31] ... new products and services, or new applications of existing products and services. Porter, in turn, in his definition developed Drucker's change as technological improvement, better methods of performing a given task, and distinguished the subject of changes, indicating that it may be a product, process, new approaches to marketing, or new forms of distribution. In this study, the understanding of innovation, in accordance with the latest Organization for Economic Co-operation and Development (OECD) Manual of Oslo, has been adopted as a new or improved product or service (or a combination thereof) that has arisen as a result of applying knowledge as a basis for novelty, utility, or value, has been implemented by a company and significantly differs from previous products or processes of the company, and has been made available to potential users (product) or put into use by the company (process). The main distinguishing feature of innovation is the use of knowledge as a basis for novelty, usefulness, or value. Another important distinguishing feature of innovation is the increase in added value in the company after its implementation [8].

Booyens and Rogerson collected and classified the results of previous research on innovation in the tourism sector [10]. The vast majority of the research concerned one selected industry. The hotel industry dominated, among others $[23,32,33]$. There were also studies on the innovativeness of selected forms of tourism, including health tourism [34], [35]. According to Booyens and Rogerson, research on innovation in all branches of the tourism sector has so far been conducted by $[10,14,36-39]$. All of the studies divided innovations into four categories: product, process, marketing, and organizational innovations $[9,40]$. Pikkemaat and Peters [41] classified five categories of innovation in tourism: productrelated, process-related, organizational, logistic, and institutional. Booyens and Rogerson [10] distinguished seven types. In addition to product, marketing, organizational, and process-related innovations, they distinguished environmental, structural, and social 
innovations. It should be noted that the latest update of the Manual of Oslo handbook has made significant changes to the classification of innovations. It distinguishes two categories: product innovation and innovation in business processes. Product innovations are defined as new or significantly improved goods or services, which significantly differ from the previous goods or services provided by the company and which was put on the market. Product innovations create products and/or services. Services are the result of production activity that changes user conditions. Within the tourism sector, there are services related to changes in the physical and mental state of a person. They include all types of services related to organization and stay of a tourist in a tourist destination, such as accommodation, guide services, and information. Innovation in business processes is a new or significantly improved business process for one or more business functions that are significantly different from the previous activity of the company and that have been introduced to the use of the company [42]. Innovations in business processes concern six different functions of a company related to business management:

- manufacturing of goods or services: this involves the activities that transform inputs into goods or services, including engineering and related works, technical research, analysis, and certification activities supporting production;

- distribution and logistics: this involves (a) transport and delivery of services, (b) warehousing, and (c) order fulfilment;

- marketing and sales and after-sales service: this involves (a) marketing methods, including advertising (promotion and product placement, product packaging), direct marketing (telemarketing), exhibitions and fairs, market research, and other activities aimed at developing new markets, (b) strategies and pricing methods, (c) sales and after-sales activities, including helpdesk points, other customer support, and customer relationship activities;

- information and communication services (ICT) within the company: this involves maintenance and provision of information and communication systems, including (a) hardware and software, (b) data processing and database, (c) maintenance and repair, and (d) website hosting and other information activities related to computers;

- administrative functions and management functions: this involves (a) strategic and general business management (making cross-functional decisions), including organizing professional duties, (b) corporate governance (law, planning, and public relations), (c) accounting, bookkeeping, auditing, payments, and other financial or insurance activities, (d) human resource management (training and education, employee recruitment, workplace organization, provision of temporary staff, payroll management, and health and medical support), (e) procurement, and (f) external relationship management with suppliers, alliances;

- engineering services and related technical services related to a company and product, and business process development: this involves activities aimed to ascertain the scope, identify, develop, or adapt a company's products or business processes. This function may be undertaken on a systematic or ad hoc basis and may be performed internally or obtained from external sources. Responsibility for these activities may lie in a separate department or departments responsible for other functions, e.g., production of goods or services [42].

Business processes can be treated as services for which the company is a customer (services provided within the company to produce a good or service and sell it); business processes can be produced internally or obtained from external sources [43]. The abovementioned division was used in this research. In addition, due to the existing research and the need to compare the obtained research results, the classification was extended by two categories: pro-environmental innovations, which were included in the innovations in product manufacturing processes as a separate category, and social innovations, which were also divided among the organization's processes as a separate category.

An important division of innovations is the classification according to the degree of originality. The literature usually distinguishes three categories of innovations [44]: 
- creative, also known as radical, constitutes a completely new product, service, or process not available on the market. It is the result of research and development works. It is of key importance in the development of the company and the tourism industry; - imitating constitutes the duplication or reproduction of products, services, and processes already existing in the tourism sector. Due to the scale of dissemination, innovations imitating solutions existing in the world, country, or region can be distinguished; - secondary, incremental (also known as apparent) constitutes minor changes consisting of improving the solution already existing in the company.

For the purposes of this study, a category of adaptive innovations should also be distinguished, consisting of the adaptation of innovative solutions from a different industry by adapting them to the conditions and specificity of a given tourism industry. These innovations have a significant level of novelty and significantly influence the diversity of innovations in the tourism sector.

According to the research by Sundbo et al. [37], tourism enterprises are dominated by secondary, incremental, nontechnological, and product innovations. This conclusion was also confirmed by the research of Hjalager [9], where imitators and adaptors (adaptation) are dominant, and Camison and Mantford-Mir [1], stating that most of the effects of implemented innovations are only recognizable in the region [38]. Similar results were obtained in the study of innovation in agritourism. Imitation innovations dominate, which consist of repeating and imitating activities that have already been carried out in space [45]. Krizaj et al. [14] indicated that product innovations are implemented twice as often as process innovations, whereas market innovations are implemented half as often as process innovations, and there are basically no institutional innovations. The dominance of incremental innovations was confirmed by Booyens and Rogerson [10]. They indicated that three-quarters of the introduced innovations concern incremental innovations, and only one-quarter of the surveyed companies implement novel innovations with a varied scope of the tourist market. They stated that product, environmental, and process innovations constituted a group of similar size. The research conducted by Jacob et al. [43] in Slovenia showed the dominance of process innovations. Cotalino indicated that they dominate the product manufacturing processes [46].

The accommodation sector, the amusement park sector, and recreation facilities dominate in the area of the implementation of innovations, according to Booyens and Rogerson [10]. The research by Krizaj et al. [14] confirmed that, taking into account the structure of the tourism sector, the accommodation sector, followed by tourist agencies and centers of tourist attractions, leads in the implementation of innovations. The accommodation sector is dominated by environmental and process innovations, while the leisure and entertainment attractions sector is dominated by structural and social innovations, according to Booyens and Rogerson [10]. Expert research on the designation of tourist entities responsible for stimulating the innovation of the tourist region showed that the greatest impact on the innovation of the tourist region is attributed to amusement parks, having the greatest impact on creating an offer for which there are no substitutes [47]. From the tourist's point of view, companies in the recreational industry are an optional good or even a luxury [23]; thus, only their high creativity can attract a client [48]. They are considered to have the best chance of gaining an innovative advantage, in particular in marketing innovation [23,48]. The above research indicates that amusement parks and other recreational facilities appear more and more frequently in the structure of entities with a high innovation index. They compete with innovations for which there are no substitutes. This discussion led to the following hypotheses:

Hypothesis 1. The highest innovativeness is achieved by enterprises offering tourist attractions related to recreation and entertainment (amusement parks, recreational facilities).

Hypothesis 2. Marketing innovations are the dominant form of innovations implemented by entities providing services related to recreation and entertainment. 


\section{Materials and Methods}

The empirical study included cross-sector studies of tourism companies on innovative activities in 2017-2019. The selection of companies for the study was identified according to the Polish Economic Activity PKD classification [49]. The following groups of entities providing services have been distinguished: accommodation, catering, transport, culture, recreation and sports, and travel agencies (Table 1).

Table 1. Characteristics of the range of tourist services by industry.

\begin{tabular}{ccl}
\hline No. & Services & \multicolumn{1}{c}{ Detailed Description of the Service Providers' Activities } \\
\hline 1 & Accommodation & $\begin{array}{l}\text { Accommodation in furnished rooms, apartments with daily cleaning services, making } \\
\text { beds (hotels, motels, guesthouses) }\end{array}$ \\
\hline 2 & Gastronomic & Activities: restaurants, cafés \\
\hline 3 & Transport & $\begin{array}{l}\text { Transport of individual passengers to places agreed by them, passenger car rental, } \\
\text { bus rental with a driver, excursion and tourist transport, activity of excursion boats } \\
\text { and similar vessels at sea, passenger transport on inland waterways: rivers, canals, } \\
\text { lakes and inside ports, bays, and at docks, rental of recreational and sports equipment: } \\
\text { excursion boats, kayaks, sailboats, bicycles, skis, etc. }\end{array}$ \\
\hline 4 & Cultural & $\begin{array}{l}\text { Cultural activities, activities of museums, botanical gardens and zoos, including } \\
\text { children's zoos, activities of nature reserves, including wildlife conservation, } \\
\text { and other cultural activities }\end{array}$ \\
\hline 5 & Recreation and sports & $\begin{array}{l}\text { Activities related to recreation and entertainment: amusement and recreation } \\
\text { activities, activities of amusement parks, water parks, rope parks, and other } \\
\text { recreational facilities, activities related to sports }\end{array}$ \\
\hline Travel agencies & $\begin{array}{l}\text { Activities of tour operators, travel brokers, and agents in the organization and sale of } \\
\text { tours, as well as other booking service activities and related activities }\end{array}$ \\
\hline
\end{tabular}

Then, on the basis of the statistical data of the Central Statistical Office in Poland, the size of the structure of tourist service providers was identified, broken down by voivodeships in which the economic activity is registered. In order to avoid the error related to the limitation of research entities due to highly aggregated data contained in the Local Data Bank (BDL) of the Central Statistical Office in Poland before starting the study, information about entities, contact details, and telephone numbers were collected from websites. A short description of the company's activity and its service offer was created on the basis of websites and customer reviews concerning innovative activities. On this basis, the enterprise was classified for the study.

The collection of research material was carried out using the diagnostic survey method with interview elements. A structured interview questionnaire was used for the study as a research tool, and the research was carried out using the computer-assisted telephone interviewing (CATI) technique. This study was qualitative in nature. This method allowed obtaining particularly important data that cannot be obtained through other methods [50]. The basic advantages of the study include the possibility of obtaining detailed information, higher objectivity, the ability to take into account the individual needs of the interlocutor and greater flexibility of the research process [51]. The research consisted of identifying detailed types of implemented innovations in tourism enterprises. The pilot studies were carried out in May and June 2019; then, the questionnaire was verified, and the basic research was carried out in the period from April to November 2020. A total of 131 interviews were conducted. The return rate achieved (the return rate is understood as the difference between consent to the interview and its conduct and the calls made, including the refusal to grant the interview) was $8 \%$.

In terms of the research issues analyzed in the article, the interview questionnaire contained semi-open questions and open-ended questions, classified as specific qualitative questions. The respondents first indicated the number of innovations implemented in 2017-2019. The next stage of the research involved semi-open and open-ended detailed 
questions. The respondents indicated the category of implemented innovations (product innovations: new product, new service; innovations in business processes: changes in the production of goods or services, including pro-environmental innovations contributing to eliminating the effects of environmental degradation; distribution and logistics, including new sales markets; new marketing methods, including new forms of promoting products/services, pricing strategies, entering a new market; new technologies, information and communication services (ICT) program in production, sales and company service; changes in the area of management in the company, including professional development, cooperation with the environment, this social environment, new work organization, engineering services, and related technical services on behalf of the company). In each category of implemented innovations, the respondents defined the scope of novelties according to the following key: a new idea not present on the market; idea from national/world tourism services; idea borrowed from another industry; new idea in the organization; improvement of an already existing solution. For each category of implemented innovation, the respondents described in detail and discussed the implemented innovations. All responses were recorded using an electronic tool and then transcribed. Further analysis was classified into groups, and the results were discussed.

The description of the research results was made with the use of the mathematical mean, weighted mean, and percentage share of categories in the studied population, as well as descriptively. The results of the qualitative study were described textually using data aggregation.

The method of linear ordering, i.e., unitization, was used to select enterprises with the highest innovation index. Linear ordering is the ordering of objects in order from best to worst, and the ordering criterion is the level of a complex phenomenon [52]. The variables of the studied phenomenon (innovations) were described by means of five differentiating values. The number of implemented innovations and their range were adopted as differentiating values. Radical, innovative innovations were assigned a value of 5 , imitative innovations of a mimetic nature occurring on the global/domestic market were assigned a value of 4 , adaptive innovations originating from a different industry were assigned a value of 3 , innovations that were new to the organization (innovations introduced with the establishment of a company) were assigned a value of 2 , and innovations improving already existing solutions were assigned a value of 1 .

In the study, the normalized values of the variables were stimulants; therefore, a higher level of innovation was described by a higher value of the indicator. The values of the indicator ranged from 0 to 1 . The value of 0 was obtained by entities that implemented only one innovation in the years 2017-2019, which was new to the organization.

In the first stage, the weighted average of innovativeness of enterprises was calculated, broken down by the tourism industry, and then the variables were normalized using the zero unitarization technique, according to Equation (1).

$$
z_{i j}=-\frac{x_{i j}-x_{j \min }}{x_{j \max }-x_{j \min }}
$$

where $z_{i j}$ is the normalized (unitized) value of the $j$-th variable for the $i$-th object, $x_{j \text { min }}$ is the minimum value of the innovation level of the $i$-th object (a value of 1 was adopted), and $x_{j \max }$ is the maximum value of the innovation level of the $i$-th object (a value of 5 was adopted).

The results were compared to the ideal model; therefore, for the variable $x_{j \min }$, i.e., the minimum value of the level of innovation, the value of 1 was adopted, and, for the variable $x_{j \max }$, i.e., the maximum value of the level of innovation, the value of 5 was adopted.

In order to determine the qualitative measure of innovativeness of enterprises, a scoring method was used, and five equal levels of innovativeness of tourism enterprises were determined (Table 2). 
Table 2. Innovation classes of the surveyed enterprises.

\begin{tabular}{ccc}
\hline Class & Class Span & The Level of Innovation \\
\hline I & $1-0.81$ & Very high innovation \\
\hline II & $0.80-0.61$ & High innovation \\
\hline III & $0.60-0.41$ & Average innovation \\
\hline IV & $0.40-0.21$ & Low innovation \\
\hline V & $0.20-0.00$ & Very low innovation \\
\hline
\end{tabular}

\section{Research Results}

The results of the survey show that $67 \%$ of the surveyed companies declared the implementation of product innovations. In the case of over $90 \%$ of enterprises, these were imitative innovations. One-fourth of the surveyed companies adopted patterns that were present on the global or domestic tourism market. The same percentage of companies implemented innovations that were new to the organization, or the changes included improvements to existing innovations in the company. In terms of innovations occurring in business processes, enterprises implemented marketing innovations $(64.12 \%$ of the surveyed enterprises declared their implementation) and innovations in logistics and distribution processes (61.07\% of the surveyed enterprises declared their implementation). Entrepreneurs adopted patterns already operating on the global and domestic market. However, it should be noted that, in the case of these two types of innovation, a significant proportion of entrepreneurs (marketing: 13.74\%; logistics: 19.85\%) used the existing marketing and logistics patterns found in other industries. Innovations in information and communication services (ICT) inside the company were implemented by $56 \%$ of the surveyed companies. Half of the surveyed enterprises declared the implementation of proenvironmental innovations related to the functioning of the company and the production of products. Innovations that improved the already existing solutions were dominant. It should also be noted that $10 \%$ of the surveyed entities adapted innovations occurring in other industries. Detailed results are presented in Table 3.

In the structure of implemented innovations, product innovations constituted the largest share $(16.86 \%)$. A slightly smaller percentage was represented by marketing innovations $(15.91 \%)$, innovations in logistics processes $(15.15 \%)$, and innovations implemented in ICT $(14.02 \%)$. Next, there were innovations introduced in the organization of work and pro-environmental innovations related to the production of products and services. However, it should be stated that no significant discrepancies between the number of implemented types of innovations were observed (Table 4). A detailed analysis of the scale of novelty of implemented innovations indicated the domination of imitative innovations that were novel and an improvement at the enterprise level $(8.33 \%+28.79 \%=37.12 \%$ of implemented innovations); subsequently, an equally large number were implemented innovations that already existed in tourist services on the domestic and global market $34.47 \%$ of implemented innovations). An important and noticeable process was the adaptation of innovations functioning in other industries; this phenomenon was dominant in the implementation of innovations in logistics processes. Detailed results are presented in Table 4.

The analysis of the structure of the types of implemented innovations in each of the surveyed tourism industries showed that accommodation services were dominated by innovations related to the implementation of ICT systems $(16.58 \%$ of all innovations implemented by hotels, followed by product innovations, in logistics and marketing processes. In catering services, innovations introduced in logistics and distribution processes (18.59\%), followed by product and marketing innovations, were dominant. In transport services, marketing and pro-environmental innovations were dominant (17.24\% each), followed by product, ICT, and work organization innovations to an equal extent. Enterprises providing recreational and sports services implemented the most product innovations (22.39\% of all implemented innovations), followed by marketing innovations. Travel agencies mainly implemented innovations in logistics and distribution processes $(16.67 \%)$, while other types of innovations were implemented equally (Table 5). 
Table 3. Structure of entities implementing innovations by types of innovations and the scale of novelty. ICT, information and communication services.

\begin{tabular}{|c|c|c|c|c|c|c|c|c|}
\hline \multirow{3}{*}{$\begin{array}{c}\% \text { of Entities Implementing Innovations } \\
\text { by Type, } N=131\end{array}$} & \multirow{3}{*}{$\begin{array}{l}\text { Product } \\
\text { Innovations }\end{array}$} & \multicolumn{7}{|c|}{ Innovations in Business Processes } \\
\hline & & \multirow[b]{2}{*}{ Logistics } & \multirow[b]{2}{*}{ ICT } & \multirow[b]{2}{*}{ Marketing } & \multicolumn{2}{|c|}{ Manufacture of Products } & \multicolumn{2}{|c|}{ Organization and Management } \\
\hline & & & & & $\begin{array}{l}\text { Entering New } \\
\text { Service Markets }\end{array}$ & $\begin{array}{c}\text { Pro- } \\
\text { Environmental } \\
\text { Innovations }\end{array}$ & $\begin{array}{c}\text { New Work } \\
\text { Organization }\end{array}$ & $\begin{array}{c}\text { Social } \\
\text { Innovations }\end{array}$ \\
\hline In total & $67.94 \%$ & $61.07 \%$ & $56.49 \%$ & $64.12 \%$ & $40.5 \%$ & $50.4 \%$ & $48.85 \%$ & $13.74 \%$ \\
\hline Radical & $6.87 \%$ & $3.05 \%$ & $2.29 \%$ & $2.29 \%$ & $3.05 \%$ & $3.05 \%$ & $6.11 \%$ & $1.53 \%$ \\
\hline World/national & $24.43 \%$ & $19.08 \%$ & $23.66 \%$ & $22.14 \%$ & $15.3 \%$ & $15.3 \%$ & $16.03 \%$ & $3.05 \%$ \\
\hline New in the organization & $3.82 \%$ & $3.82 \%$ & $4.58 \%$ & $5.34 \%$ & $6.11 \%$ & $6.87 \%$ & $1.53 \%$ & $1.53 \%$ \\
\hline Improvement of an already existing solution & $19.85 \%$ & $15.27 \%$ & $14.50 \%$ & $20.61 \%$ & $10.7 \%$ & $16.0 \%$ & $16.79 \%$ & $2.29 \%$ \\
\hline
\end{tabular}

Table 4. Structure of implemented innovations according to the scale of novelty and type of implemented innovations.

\begin{tabular}{|c|c|c|c|c|c|c|c|c|c|}
\hline \multirow{2}{*}{\multicolumn{2}{|c|}{$\%$ of Implemented Innovations, $N=528$}} & \multirow[b]{2}{*}{$\begin{array}{c}\text { Product } \\
\text { Innovations }\end{array}$} & \multirow[b]{2}{*}{ Logistics } & \multirow[b]{2}{*}{ ICT } & \multirow[b]{2}{*}{ Marketing } & \multicolumn{2}{|c|}{ Manufacture of Products } & \multicolumn{2}{|c|}{ Organization and Management } \\
\hline & & & & & & $\begin{array}{l}\text { Entering New } \\
\text { Service Markets }\end{array}$ & $\begin{array}{l}\text { Pro-Environmental } \\
\text { Innovations }\end{array}$ & $\begin{array}{c}\text { New Work } \\
\text { Organization }\end{array}$ & $\begin{array}{c}\text { Social } \\
\text { Innovations }\end{array}$ \\
\hline In total & & $16.86 \%$ & $15.15 \%$ & $14.02 \%$ & $15.91 \%$ & $10.04 \%$ & $12.50 \%$ & $12.12 \%$ & $3.41 \%$ \\
\hline Radical & $7.01 \%$ & $1.70 \%$ & $0.76 \%$ & $0.57 \%$ & $0.57 \%$ & $0.76 \%$ & $0.76 \%$ & $1.52 \%$ & $0.38 \%$ \\
\hline World/national & $34.47 \%$ & $6.06 \%$ & $4.73 \%$ & $5.87 \%$ & $5.49 \%$ & $3.79 \%$ & $3.79 \%$ & $3.98 \%$ & $0.76 \%$ \\
\hline Borrowed from another industry & $21.40 \%$ & $3.22 \%$ & $4.92 \%$ & $2.84 \%$ & $3.41 \%$ & $1.33 \%$ & $2.27 \%$ & $2.08 \%$ & $1.33 \%$ \\
\hline New in the organization & $8.33 \%$ & $0.95 \%$ & $0.95 \%$ & $1.14 \%$ & $1.33 \%$ & $1.52 \%$ & $1.70 \%$ & $0.38 \%$ & $0.38 \%$ \\
\hline Improvement of an already existing solution & $28.79 \%$ & $4.92 \%$ & $3.79 \%$ & $3.60 \%$ & $5.11 \%$ & $2.65 \%$ & $3.98 \%$ & $4.17 \%$ & $0.57 \%$ \\
\hline
\end{tabular}


The analysis of the structure of implemented innovations within the tourism industry showed that, in accommodation services, more than half of the implemented innovations were new on the global and domestic market (51\%). In the case of other industries, innovations consisting of the improvement of already existing solutions in the company were dominant (over $30 \%$ of all implemented innovations), and over $10 \%$ were innovations new to the organization. It should be noted that, in the group of radical innovations, the industry providing recreation and sports services implemented the highest percentage (15\%) (Table 6). In the group of innovations adopted from another industry, the largest percentage was implemented by the catering industry $(28 \%)$. Detailed results are presented in Table 6 .

The research indicates that for each enterprise providing tourist services, there were 4.03 implemented innovations of different scales of novelty. Taking into account the importance of innovation according to the scale of its novelty, it follows that, on average, there were 2.74 innovations for each enterprise (weighted average). This means that the implemented innovations were of lower importance due to the scale of novelty. A detailed analysis of the average number of implemented innovations in individual tourist services showed that the largest number of innovations was implemented in sports and recreation (6.09) and cultural (5.88) services. Providers of accommodation services implemented the lowest number of innovations (3.98). The scale of novelty of the implemented innovations indicates that innovations with a higher scale of novelty than in other tourism industries were being implemented in accommodation services (3.23). A detailed distribution of the data is presented in Table 7.

Taking into account the number of implemented innovations, it can be assumed that the highest innovativeness was achieved by enterprises providing recreation and sports services. In accordance with the methodology adopted by the author, these enterprises qualified with the index of 0.41 to the third innovation class, which was the highest class achieved by the surveyed enterprises. This class has a higher innovation index; it was achieved by enterprises providing accommodation services, i.e., 0.56. Moreover, the innovation index of enterprises providing recreational and sports services was lower by 0.03 points than the value of the index calculated for all surveyed enterprises. The results of the performed analysis indicate that the formulated hypothesis (the highest innovativeness is achieved by enterprises offering tourist attractions related to recreation and entertainment (amusement parks, recreational facilities) should be refuted. The companies providing accommodation services were the most innovative.

The results of the study indicate that the implementation of product innovations was dominant in recreational and sports enterprises, with $83.33 \%$ of the surveyed companies implementing them. These are innovations that improve the existing innovations and new ones in the organization. It is important that enterprises implemented the highest percentage of radical innovations among the surveyed (15\%), with these innovations implemented by $5.6 \%$ of the surveyed enterprises. The highest percentage of implemented innovations in marketing processes was observed in transport and culture enterprises. The vast majority of these innovations were innovations consisting of improving solutions already existing in the company. The results of the research indicate that the second hypothesis (marketing innovations are the dominant form of innovation implemented by entities providing services related to recreation and entertainment) was verified negatively. 
Table 5. Structure of implemented innovations by tourism industries and types of innovations.

\begin{tabular}{|c|c|c|c|c|c|c|c|c|}
\hline \multirow{2}{*}{$\begin{array}{c}\text { Structure Innovations by Tourism Industries and } \\
\text { Types of Innovations }\end{array}$} & \multirow{2}{*}{$\begin{array}{c}\text { Product } \\
\text { Innovations }\end{array}$} & \multirow[b]{2}{*}{ Logistics } & \multirow[b]{2}{*}{ ICT } & \multirow[b]{2}{*}{ Marketing } & \multicolumn{2}{|c|}{ Manufacture of Products } & \multicolumn{2}{|c|}{ Organization and Management } \\
\hline & & & & & $\begin{array}{c}\text { Entering New } \\
\text { Service Markets }\end{array}$ & $\begin{array}{l}\text { Pro-Environmental } \\
\text { Innovations }\end{array}$ & $\begin{array}{c}\text { New Work } \\
\text { Organization }\end{array}$ & $\begin{array}{c}\text { Social } \\
\text { Innovations }\end{array}$ \\
\hline$\%$ of implemented innovations in accommodation services, $N=187$ & $16.04 \%$ & $15.51 \%$ & $16.58 \%$ & $14.97 \%$ & $9.63 \%$ & $13.37 \%$ & $10.16 \%$ & $3.74 \%$ \\
\hline$\%$ of implemented innovations in catering services, $N=156$ & $17.31 \%$ & $18.59 \%$ & $11.54 \%$ & $16.03 \%$ & $9.62 \%$ & $12.82 \%$ & $11.54 \%$ & $2.56 \%$ \\
\hline$\%$ of implemented innovations in transport services, $N=29$ & $13.79 \%$ & $10.34 \%$ & $13.79 \%$ & $17.24 \%$ & $10.34 \%$ & $17.24 \%$ & $13.79 \%$ & $3.45 \%$ \\
\hline$\%$ of implemented innovations in cultural services, $N=35$ & $17.14 \%$ & $11.43 \%$ & $14.29 \%$ & $22.86 \%$ & $5.71 \%$ & $8.57 \%$ & $17.14 \%$ & $2.86 \%$ \\
\hline$\%$ of implemented innovations in recreation and sports services, $N=67$ & $22.39 \%$ & $8.96 \%$ & $13.43 \%$ & $16.42 \%$ & $11.94 \%$ & $10.45 \%$ & $13.43 \%$ & $2.99 \%$ \\
\hline$\%$ of implemented innovations in travel agency services, $N=48$ & $12.50 \%$ & $16.67 \%$ & $12.50 \%$ & $12.50 \%$ & $12.50 \%$ & $10.42 \%$ & $14.58 \%$ & $4.17 \%$ \\
\hline
\end{tabular}

Table 6. Structure of implemented innovations by tourism industries and the scale of new products.

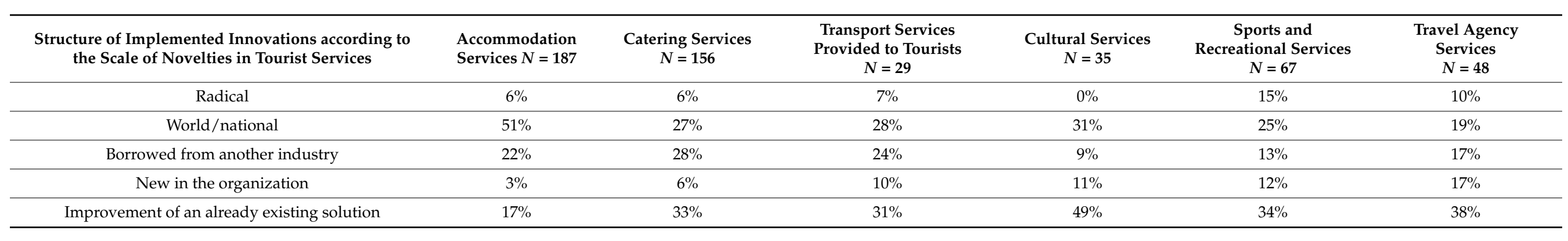

Table 7. Innovativeness of enterprises by tourism industries.

\begin{tabular}{|c|c|c|c|c|}
\hline $\begin{array}{c}\text { Entities Implementing Innovations } \\
\text { by Type }\end{array}$ & $\begin{array}{l}\text { Average Number of Implemented Innovations } \\
\text { per Enterprise in the Industry }\end{array}$ & $\begin{array}{l}\text { Weighted Average according to the Scale of Novelty of } \\
\text { Implemented Innovations per Enterprise in the Industry }\end{array}$ & Innovation Index & The Level of Innovation \\
\hline In total & 4.03 & 2.74 & 0.44 & Average \\
\hline Accommodation services & 3.98 & 3.23 & 0.56 & Average \\
\hline Catering services & 4.0 & 2.61 & 0.40 & Low \\
\hline Transport services provided to tourists & 4.83 & 2.59 & 0.40 & Low \\
\hline Cultural services & 5.88 & 2.11 & 0.28 & Low \\
\hline Recreational and sports services & 6.09 & 2.63 & 0.41 & Average \\
\hline Travel agency services & 4.36 & 2.31 & 0.33 & Low \\
\hline
\end{tabular}




\section{Discussion}

Product innovations are dominant in Polish tourism enterprises. Similar results were obtained by Sundbo et al. in their research of companies in Denmark and Spain [37]. However, there were similar levels of innovations implemented in marketing, distribution, and logistics processes, as well as ICT. Jakob's research on the Balearic Islands in Spain indicated the domination of process innovations [43], while research conducted in the West Cape region in South Africa by Booyens and Rogerson [10] stated that product, environmental, and process innovations were of similar level. Most of the implemented innovations were secondary, incremental innovations, which are an improvement of already existing solutions in the company. Much fewer imitative and adaptive innovations were implemented, which are the adaptation of innovations from another industry to their own conditions. Similar types of innovations were implemented by entrepreneurs operating, among others, in Denmark and Spain, West Cape South Africa, and Slovenia, as indicated by the research conducted by Hjalager [9], Krizaj et al. [14], and Booyens et al. [10]. The highest percentage of secondary, incremental innovations was characteristic of product innovations in marketing, organizational, and management processes in the field of work organization and pro-environmental processes. In turn, the largest share of imitative innovations was implemented in product innovations, with slightly lower shares in marketing processes and ICT. Adaptive innovations were dominant in distribution and logistics processes.

Our research showed a much lower percentage of companies implementing novel innovations than the Krizaj research [14] carried out in Slovakia. Moreover, a lack of engineering innovations was determined, although some of the respondents included them in the group of innovations in product manufacturing processes [12]. The analysis of innovations in the product manufacturing processes showed that, in this group, most innovations were of an adaptive nature in the processes of distribution and logistics. A very small percentage of enterprises implemented novel innovations.

Taking into account the structure of the tourism sector, the leaders in the implementation of innovations were the accommodation sector and the sector of amusement parks and recreation facilities, which is in line with the results of the research by Booyens and Rogerson [10] and Krizaj et al. [14], obtained in West Cape South Africa and in Slovenia, respectively.

In accommodation services, innovations in ICT processes were dominant, in line with the results of Booyens and Rogerson [10], followed by product innovations in distribution and logistics processes, as well as marketing processes, which was not confirmed by Booyens and Rogerson, as, in their research, environmental innovations were prevalent. In the recreational and sports industry, the dominant innovations were product innovations and innovations in marketing processes, with a similar level, consistent with the results from Australia in the study by Diviseker [21] in relation to marketing innovations. One should agree that, in optional or even luxury services, only their high creativity can attract the customer [21]. In the case of the surveyed companies, we saw this creativity in product innovations. This was evidenced by a fairly significant percentage of novel innovations. According to the author, the catalog of optional services should be extended to include transport services provided to tourists at the tourist reception site, as well as cultural services. In our research, in the case of these service providers, the highest percentage of implemented innovations were those in marketing processes. In the case of transport services, environmental innovations were implemented to the same extent in product manufacturing processes.

In catering services, innovations introduced in distribution and logistics processes, followed by product and marketing innovations, were dominant. These results slightly differ from those related to the structure of implemented innovations in catering obtained by Booyens et al. [10]. However, it should be noted that the present research showed a slightly different breakdown structure of innovation. From the group of organizational innovations, innovations in distribution and logistics processes, innovations in product manufacturing processes, and innovations in organization and management processes 
were distinguished. In addition, Booyen et al. calculated the structure of innovation within each of the researched types of innovations, and, in this research, the structure of the implemented innovations by each of the industries was calculated so that they could be compared. These innovations were primarily secondary, incremental, and then adaptive, as well as imitative. In transport services, marketing and pro-environmental innovations dominated, followed to an equal extent by product innovations in ICT, as well as work organization processes. Just as in catering services, these were primarily secondary, incremental, and imitative innovations. Enterprises providing cultural services implemented the most innovations in marketing processes. Half of these innovations were secondary, incremental innovations.

Enterprises providing recreational and sports services implemented the most product innovations followed by innovations in marketing processes. The vast majority were secondary, incremental innovations. It should be noted, however, that about one-fifth of innovations were novel innovations with a different scope of the tourist market. Travel agencies primarily implemented innovations in distribution and logistics processes. The vast majority were secondary, incremental innovations.

\section{Conclusions}

The largest percentage of tourism industry enterprises implemented product innovations. Slightly fewer enterprises implemented innovations in the processes of marketing, distribution, and logistics, as well as ICT.

Enterprises implemented imitative innovations; among them, one-fifth of enterprises implemented secondary, incremental innovations, which are an improvement of already existing solutions in the company. One-fourth of the surveyed companies adopted patterns that are present on the global or domestic tourism market. Slightly more than one-tenth of companies implemented adaptive innovations, adopting patterns from other industries and adapting them to their conditions. This process was dominant in the case of adapting innovations in distribution and logistics processes. A very small percentage of enterprises implemented novel innovations.

The structure of implemented innovations reflected the above distribution. Product innovations were dominant. Slightly fewer innovations were implemented in the processes of marketing, distribution, and logistics, as well as ICT. However, it should be stated that no significant discrepancies between the number of implemented types of innovations were observed.

The structure of the implemented innovations was dominated by secondary, incremental innovations. The highest percentage occurred in product innovations, as well as in marketing, organizational, and management processes in the field of work organization and pro-environmental innovations. Imitation innovations were implemented slightly less, mainly on the global and domestic market. These innovations constituted one-third of all implemented innovations. Their largest share occurred in product innovations, with a slightly lower share in marketing processes, as well as ICT. An important and noticeable process is the phenomenon of adapting innovations functioning in other industries. Adaptive innovations dominate distribution and logistics processes.

In accommodation services, innovations in ICT processes were dominant, followed by product innovations, distribution, and logistics processes, as well as marketing processes. Half of the implemented innovations were imitative innovations occurring on the global and domestic market. Adaptive innovations accounted for a large proportion of innovations, and secondary, incremental innovations were slightly less prevalent.

In catering services, innovations introduced in distribution and logistics processes were dominant, followed by product and marketing innovations. These innovations were primarily secondary, incremental, and then adaptive, as well as imitative. In transport services, marketing and pro-environmental innovations were dominant, followed by product innovations to an equal extent, in ICT and work organization processes. As in the case of catering services, these innovations were primarily secondary, incremental, and imitative. 
Enterprises providing cultural services implemented the most innovations in marketing processes. Half of these innovations were secondary, incremental innovations.

Enterprises providing recreational and sports services implemented the most product innovations, followed by innovations in marketing processes. The vast majority were secondary, incremental innovations. It should be noted, however, that about one-fifth of innovations were innovative innovations with a varied scope of the tourist market. Travel agencies primarily implemented innovations in distribution and logistics processes. The vast majority of innovations were of a secondary, incremental nature.

The highest, average innovativeness was characteristic of enterprises providing accommodation services, as well as recreation and sports services.

Summing up, it should be stated that the tourism industry is characterized by an average and low level of innovativeness. Enterprises providing accommodation services, as well as recreational and sports services, are characterized by an average level of innovativeness.

Secondary, incremental product innovations dominate in recreational and sports services. However, it should be said that these companies implement much more novel innovations than others. Accommodation services implement the most imitative innovations in ICT processes. Catering services and travel agencies lead in the implementation of innovations in distribution and logistics processes. In the case of catering services, these are definitely adaptive innovations, and, in travel agencies, secondary, incremental innovations dominate. Secondary, incremental innovations in marketing processes are dominant in transport and cultural services. The largest percentage of pro-environmental innovations is implemented by transport service companies. Generally speaking, it should be stated that the tourism sector operating in Poland is characterized by a comparable structure and types of innovations implemented by enterprises operating in other countries of the world, e.g., Balearic Islands in Spain, Denmark and Spain, Slovenia, West Cape South Africa, and Australia.

\section{Contribution to Science}

In this article, four areas were identified as a new contribution to science. Firstly, a conceptual framework was adopted for the analysis of the innovation process of tourism enterprises by applying the ranking of implemented innovations as a function of a scale of novelty. This is an important contribution considering that, so far, the innovativeness of tourism enterprises has been calculated on the basis of the number of implemented innovations. However, taking into account the effects of implemented innovations and changes in the enterprise as a result of their introduction, one cannot treat incremental innovation and innovation, which is a novelty on a national or even world scale, on par. The proposed conceptual framework can be used as a basis for similar empirical work and/or can be modified and extended to suit specific research objectives.

Secondly, the study found that innovations in the tourism industry are widely implemented by companies. The study confirmed the dominance of secondary, incremental innovations, consistent with other studies, such as Sundbo et al. [37], Eide et al. [36], Alsos et al. [12], Clausen and Madsen, [7], Rodriguez et al. [3], and Williams [4]. However, attention should also be paid to the significant percentage of implemented imitative innovations, transferring patterns already existing in the world and in the country. High activity was observed in the field of adaptive innovations associated with adapting innovations from another industry to the conditions of the company, which positively affects the differentiation of the types of innovations. This diversified structure testifies to the commitment and activity of companies in the field of innovative activities. As noted by Hajlager [53], Sundbo and Toivonen [54], and Fagerberg [16], strategic growth is important for the competitiveness of tourism companies, as it collectively leads to radical changes, increases productivity, and contributes to improving the economic situation. However, a disturbing phenomenon is the very low percentage of novel innovations, lower than indicated by the research by Krizaj et al. [14]. It should be stated that, from the point of view of the assessment of the impact of innovation on market behavior [55], in the tourism sector, there are no 
so-called disruptive innovations that could have a decisive impact on market changes and replace the existing and constantly improved products, services, and processes. There are sustaining innovations that do not affect the market changes and compete with the existing solutions on the same terms [56]. The occurrence of this phenomenon over a longer period of time significantly reduces the competitiveness of this sector. This study contributes to the development of the literature because, as pointed out by Thomas et al. [5] and Brooker and Joppe [6], incremental innovations have been the subject of minimal research attention.

Thirdly, as an empirical study, a substantial level of useful information was provided about the generic structure of implemented innovations. The study showed that the structure of the innovations implemented in the tourism industry is evolving. Earlier research by Sundbo et al. [37] indicated the dominance of product innovation. Jakob's research indicated the dominance of process innovations, while Booyens and Rogerson [10] indicated that product, environmental, and process innovations were of a similar level. This study showed that, despite the slight advantage of product innovations, innovations implemented in the processes of marketing, distribution, and logistics, as well as ICT, constitute a similar level, which indicates a significant evaluation of innovation processes in tourist services. An important contribution of this research is the identification of innovations in advanced business processes taking place in a tourism enterprise. It should be noted that the breakdown of innovation introduced by the OECD in 2018 made it much easier to identify and categorize innovations [42]. The novelty is the identification of innovations implemented in the processes of distribution and logistics, as well as the processes of manufacturing products, and distinguishing them from the group of organization and management processes. As indicated by the results of the study, innovations in distribution and logistics processes were not very diverse in the tourism sector, as evidenced by the dominant number of implemented adaptive innovations, i.e., patterns transferred from other industries. These are processes that are developing quite quickly in the tourism industry, especially in catering services and travel agencies. This process is associated with the need to distribute product innovations, as well as with the introduction of innovations within the company related to entering new service markets. The new classification of types of innovations also allowed clearly indicating the place of pro-environmental innovations in business processes.

Fourth, the research contributes to the development of literature on innovation in the tourism sector. The research concerned innovativeness within the industry and covered the sectors of accommodation, catering, transport, culture, recreation, and sports services, as well as travel agencies. As indicated by the literature research, there are few cross-industry studies; therefore, this research extends the range of already known results. Business innovation surveys confirmed the results of Booyen et al. [10] and Sundbo et al. [37]. The most innovative industry involved enterprises providing accommodation services, followed by enterprises providing recreation and sports services. The remaining industries showed a low level of innovation. However, this research contributes to the debate on the leading forms of innovation implemented by the most innovative industries. In accommodation services, innovations in ICT processes were dominant, in line with the results of Booyens and Rogerson, followed by a similar level of product innovations in distribution and logistics processes, as well as marketing processes, which was not confirmed by Booyens and Rogerson, as, in their research, environmental innovations were dominant. One should agree that, in optional or even luxurious services, only their high creativity can attract the customer [21]. Therefore, such services should be dominated by innovations in marketing processes. Their conclusions were related only to the recreational services provided in the tourist region. According to the authors, the catalog of optional services should be extended to include transport services provided to tourists at the tourist reception site and cultural services. The results of the study indicate that the creativity of providers of recreational and sports services translated into the implementation of two types of innovations, product and marketing innovations, which quite significantly exceeded other types of innovations. Moreover, these innovations showed quite a significant 
share of novel innovations. In the case of the transport and culture industries, marketing innovations dominated, but it should be noted that the transport industry introduced a high percentage of pro-environmental innovations in the product manufacturing processes.

Summing up, it should be stated that innovativeness is a process occurring in the tourism sector in Poland. It should be stated that, from the point of view of assessing the impact of innovation on market behavior in the tourism sector, there are no disruptive innovations that could have a decisive impact on market changes and replace the existing and constantly improved products, services, and processes. There are sustaining innovations that improve the functioning of companies, which do not affect the market changes, and compete with the existing solutions on the same terms. However, an important part of innovation constitutes incremental and adaptive innovations; this process testifies to the development of tourism companies and contributes to the improvement of the situation in the entire economy.

The epidemiological situation related to COVID-19 is important from the point of view of the future goals of innovative activities of tourism enterprises. Research shows that the tourism sector, especially accommodation and catering, includes companies most vulnerable to economic shocks [57]. As a result of the COVID-19 pandemic, for example, the Japanese tourism industry recorded a $61 \%$ decrease in tourism consumption in the first half of 2020 [58]. In order to counteract this, the governments of various countries supported the tourism market by supporting promotional campaigns, issuing discount coupons for tourist stays, along with financial support for subsidizing employee salaries [57,58]. Moreover, as indicated by the latest research, the structure of implemented innovations should change from product innovations to marketing innovations as the most effective tool for solving the problem and reaching the demand market by constantly expanding the base of contacts with contractors [59]. In turn, the demand market expects the creation of so-called "safe vacation" offers, whereby $42.3 \%$ of the surveyed tourists vacationing in the Azores declared a willingness to pay more for a "safe vacation" offer [60]. The above studies related to the COVID-19 situation suggest serious changes in the innovative activity of the tourism sector, which, unfortunately, are not observed among Polish entrepreneurs. This problem is one of the most important future research directions.

The results of the study can help to develop management programs and strategies critical to initiating innovation processes, in particular radical innovations.

Author Contributions: This work was written independently by one author. All authors have read and agreed to the published version of the manuscript.

Funding: This work was supported by the Ministry of Science and Higher Education of Republic of Poland.

Institutional Review Board Statement: Not applicable.

Informed Consent Statement: Not applicable.

Data Availability Statement: Not applicable.

Conflicts of Interest: The author declares no conflict of interest. The funders had no role in the design of the study; in the collection, analyses, or interpretation of data; in the writing of the manuscript, or in the decision to publish the results.

\section{References}

1. César, C.; Vicente, M.M.-M. Measuring innovation in tourism from the Schumpeterian and the dynamic-capabilities perspectives. Tour. Manag. 2012, 33, 776-789. [CrossRef]

2. Brouder, P.; Eriksson, R.H. Staying Power: What Influences Micro-firm Survival in Tourism? Tour. Geogr. 2013, 15, 125-144. [CrossRef]

3. Rodríguez, I.; Williams, A.; Hall, C.M. Tourism Innovation Policy: Implementation and Outcomes. Ann. Tourism Res. 2014, 49, 76-93. [CrossRef]

4. Williams, A.M. Tourism innovation; products, processes and people. In The Wiley Blackwell Companion to Tourism; Lew, A.A., Hall, C.M., Williams, A.M., Eds.; Wiley Blackwell: Chichester, UK, 2014; pp. 168-177. 
5. Thomas, R.; Shaw, G.; Page, J.P. Understanding Small Firms in Tourism: A Perspective on Research Trends and Challenges. Tourism Manag. 2011, 32, 963-976. [CrossRef]

6. Brooker, E.; Joppe, M. Developing a Tourism Innovation Typology: Leveraging Liminal Insights. J. Travel Res. 2013, 53, 500-508. [CrossRef]

7. Clausen, T.H.; Madsen, E.L. Innovations, their knowledge sources and their effects in experience-base tourism. In Handbook of Research on Innovation in Tourism Industries; Alsos, G.A., Eide, D., Madsen, E.L., Eds.; Edward Elgar: Cheltenham, UK, 2014; pp. 113-131.

8. Hall, C.M.; Williams, A.M. Tourism and Innovation; Routledge: Oxford, UK, 2008.

9. Hjalager, A.M. A review of innovation research in tourism. Tour. Manag. 2010, 31, 1-12. [CrossRef]

10. Booyens, I.; Rogerson, C.M. Tourism innovation in the global South: Evidence from the Western Cape, South Africa. Int. J. Tour. Res. 2016, 18, 515-524. [CrossRef]

11. Dziemdziela, P.; Krzyżanowska, K. Działalność innowacyjna małych i średnich przedsiębiorstw w Polsce. Tur. i Rozw. Reg. 2020, 89-100. [CrossRef]

12. Alsos, G.A.; Eide, D.; Madsen, E.L. (Eds.) Innovation in tourism industries. In Handbook of Research on Innovation in Tourism Industries; Edward Elgar: Cheltenham, UK, 2014; pp. 1-26.

13. Hoarau, H.; Kline, C. Science and industry: Sharing knowledge for innovation. Ann. Tour. Res. 2014, 46, 44-61. [CrossRef]

14. Krizaj, D.; Brodnik, A.; Bukovec, B. A Tool For Measurement of Innovation Newness and Adoption in Tourism Firms. Int. J. Tour. Res. 2012, 16, 113-125. [CrossRef]

15. Martínez-Román, J.A.; Tamayo, J.A.; Gamero, J.; Romero, J.E. Innovativeness and business performances in tourism SMEs. Ann. Tour. Res. 2015, 54, 118-135. [CrossRef]

16. Fagerberg, J. Innovation: A guide to the literature. In The Oxford Handbook of Innovation; Fagerberg, J., Mowery, D., Nelson, R., Eds.; Oxford University Press: Oxford, UK, 2013; p. 1e26.

17. Pappas, N. Hotel decision-making during multiple crises: A chaordic perspective. Tour. Manag. 2018, 68, 450-464. [CrossRef]

18. Thomas, R.; Wood, E. The absorptive capacity of tourism organisations. Ann. Tour. Res. 2015, 54, 84-99. [CrossRef]

19. Thomas, R.; Wood, E. Innovation in tourism: Re-conceptualising and measuring the absorptive capacity of the hotel sector. Tour. Manag. 2014, 45, 39-48. [CrossRef]

20. Soames, T.; Brunker, L.; Talgaswatta, D. Competition, innovation and productivity in Australian businesses. Res. Pap. 2011, 36, 88-106.

21. Divisekera, S.; Nguyen, V.K. Determinants of innovation in tourism evidence from Australia. Tour. Manag. 2018, 67, 157-167. [CrossRef]

22. Topsakal, Y.; Science, A. Strategic innovation: An empirical study on hotel firms operating in Antalya region. Adv. Hosp. Tour. Res. 2014, 2, 16-29.

23. Mattsson, J.; Orfila-Sintes, F. Hotel Innovation and Its Effects on Business Performance. Int. J. Tour. Res. 2014, 16, 388-398. [CrossRef]

24. Hara, T.; Naipaul, S. Agritourism as a Catalyst for Improving the Quality of the Life in Rural Regions: A Study from a Developed Country. J. Qual. Assur. Hosp. Tour. 2008, 9, 1-33. [CrossRef]

25. Brouder, P. Creative Outposts: Tourism's Place in Rural Innovation. Tour. Plan. Dev. 2012, 9, 383-396. [CrossRef]

26. Carlisle, S.; Kunc, M.; Jones, E.; Tiffin, S. Supporting innovation for tourism development through multi-stakeholder approaches: Experiences from Africa. Tour. Manag. 2013, 35, 59-69. [CrossRef]

27. Hjalager, A.M. 100 Innovations That Transformed Tourism. J. Travel Res. 2015, 55, 3-21. [CrossRef]

28. Schumpeter, J. Teoria Rozwoju Gospodarczego; Wydawnictwo Naukowe PWN: Warszawa, Poland, 1960.

29. Porter, M.E. The Competetive Advantage of Nations; The Macmillan Press Ltd.: London, UK, 1990.

30. Bessant, T.J.; Thor, A.M.; Tidd John Bessant, A.M.T. Zarządzanie Innowacjami. Interpretacja Zmian Technologicznych, Rynkowych $i$ Organizacyjnych; Wolters Kluwer Business: Warszawa, Poland, 2013.

31. Ducker, P.F. Innowacje i Prze Dsiębiorczość. Praktyka i Zasady; Polskie Wydawnictwo Ekonomiczne: Warszawa, Poland, 1992.

32. Orfila-Sintes, F.; Crespí-Cladera, R.; Martínez-Ros, E. Innovation activity in the hotel industry: Evidence from Balearic Islands. Tour. Manag. 2005, 26, 851-865. [CrossRef]

33. Neuhofer, B.; Buhalis, D.; Ladkin, A. A Typology of Technology-Enhanced Tourism Experiences. Int. J. Tour. Res. 2014, 16, 340-350. [CrossRef]

34. Panfiluk, E. Aesthetic medicine tourism-Nature and scope of the services. Eng. Manag. Prod. Serv. 2016, 8, 71-79. [CrossRef]

35. Szymańska, E.; Dziedzic, E.; Panasiuk, A.; Panfiluk, E.; Rutkowski, A. Innowacje w Turystyce Zdrowotnej; Wydawnictwo Difin: Warszawa, Poland, 2017.

36. Eide, D.; Fuglsang, L.; Sundbo, J. Management challenges with the maintenance of tourism experience concept innovations: Toward a new research agenda. Tour. Manag. 2017, 63, 452-463. [CrossRef]

37. Sundbo, J.; Orfila-Sintes, F.; Sørensen, F. The Innovative Behaviour of Tourism Firms—Comparative Studies of Denmark and Spain. Res. Policy 2007, 36, 88-106. [CrossRef]

38. Jacob, M.; Tintore, J.; Aguilo, E.; Bravo, A.; Mulet, J. Innovation in the Tourism Sector: Results from a Pilot Study in the Balearic Islands. Tour. Econ. 2003, 9, 279-295. [CrossRef]

39. Verreynne, M.L.; Williams, A.M.; Ritchie, B.W.; Gronum, S.; Betts, K.S. Innovation diversity and uncertainty in small and medium sized tourism firms. Tour. Manag. 2019, 72, 257-269. [CrossRef] 
40. Tejada, P.; Moreno, P. Patterns of innovation in tourism “Small and Medium-size Enterprises". Serv. Ind. J. 2013, 33, 749-758. [CrossRef]

41. Pikkemaat, B.; Peters, M. Towards the Measurement of Innovation-A Pilot Study in the Small and Medium Sized Hotel Industry. J. Qual. Assur. Hosp. Tour. 2005, 6, 89-112. [CrossRef]

42. Organization for Economic Co-operation and Development (OECD) Eurostat. Oslo Manual 2018; OECD: Paris, France, 2018.

43. Jacob, M.; Florido, C.; Aguiló, E. Research note: Environmental innovation as a competitiveness factor in the Balearic Islands. Tour. Econ. 2010, 16, 755-764. [CrossRef]

44. Białoń, L. Zarzadzanie Działalnością Innowacyjna; Wydawnictwo PLACET: Warszawa, Poland, 2010.

45. Roman, M.; Roman, M.; Prus, P. Innovations in agritourism: Evidence from a region in Poland. Sustainability 2020, $12,4858$. [CrossRef]

46. Catalino, A.H.; Lizardo, M. Agriculture, Environmental Services and Agro-Tourism in the Dominican Republic. J. Agric. Dev. Econ. 2004, 1, 87-116.

47. Panfiluk, E. Management of the Tourist Region-Identification of the determinants of Innovation. Trans. Bus. Econ. 2021, 18, 106-116.

48. Divisekera, S.; Nguyen, V.K. Drivers of innovation in tourism: An econometric study. Tour. Econ. 2018, 24, 998-1014. [CrossRef]

49. Rozporządzenie Rady Ministrów w sprawie Polskiej Klasyfikacji Działalności (PKD) [Regulation of the Council of Ministers on the Polish Classification of Activities] 2007 z dnia 24-12-2007 r. Available online: www.pkd.com.pl/wyszukiwarka/lista_pkd (accessed on 15 October 2019).

50. Stokes, D.; Bergin, R. Methodology or "methodolary"? An ewaluation of focus groups and depth interviews. Qual. Mark. Res. 2006, 9, 2006. [CrossRef]

51. Kaczmarek, M.; Olejnik, I.; Springer, A. Badania Jakościowe-Metody i Zastosowania; CeDeWu: Warszawa, Poland, 2013.

52. Walesiak, M. Przegląd formuł normalizacji wartości zmiennych oraz ich własności w statystycznej analizie wielowymiarowej. Przeglad Stat. 2014, 61, 363-372.

53. Hjalager, A.M.; von Gesseneck, M.J. Capacity-, system- and mission-oriented innovation policies in tourism-characteristics, measurement and prospects. J. Policy Res. Tour. Leis. Events 2020, 12, 197-216. [CrossRef]

54. Sundbo, M.T.J. User-Based Innovation in Services; Edward Edgar: Cheltenham, UK, 2011.

55. Christensen, C.M.; Raynor, M.E. The Innovator's Solution; Harvard Bu: Boston, MA, USA, 2003.

56. Boratyńska-Sala, A.; Knosala, R.; Jurczyk-Bunkowska, M. Zarządzanie Innowacjami [Innovation Management]; PWE: Warszawa, Poland, 2013.

57. Roman, M.; Niedziółka, A.; Krasnodębski, A. Respondents' involvement in tourist activities at the time of the COVID-19 pandemic. Sustainability 2020, 12, 9610. [CrossRef]

58. Kitamura, Y.; Karkour, S.; Ichisugi, Y.; Itsubo, N. Evaluation of the economic, environmental, and social impacts of the COVID-19 pandemic on the japanese tourism industry. Sustainability 2020, 12, 302. [CrossRef]

59. Sánchez-Teba, E.M.; García-Mestanza, J.; Rodríguez-Fernández, M. The application of the inbound marketing strategy on costa del sol planning \& tourism board. Lessons for post-covid-19 revival. Sustainability 2020, 12, 9926. [CrossRef]

60. Castanho, R.A.; Couto, G.; Pimentel, P.; Sousa, Á.; Carvalho, C.; da Batista, M.G. The Impact of SARS-CoV-2 Outbreak on the Accommodation Selection of Azorean Tourists. A Study Based on the Assessment of the Azores Population's Attitudes. Sustainability 2020, 12, 9990. [CrossRef] 